\title{
ANALISIS KOMPONEN PENILAIAN PADA RENCANA PELAKSANAAN PEMBELAJARAN SEBAGAI ACUAN PENGEMBANGAN KURIKULUM DIKLAT TEKNIS SUBSTANTIF GURU
}

\section{ANALYZE ASSESSMENT COMPONENT ON LESSON PLAN \\ AS THE BASIC OF CURRICULUM TRAINING DEVELOPMENT ON TECHNICAL SUBSTANTIVE TRAINING FOR TEACHER}

\author{
Nurul Kamilati \\ Balai Diklat Keagamaan Semarang \\ Jl. Untung Suropati Kav 69-70 Bambankerep, Ngaliyan Semarang \\ email:nurul_kamilati@yahoo.com
}

Naskah Diterima: 8 Januari 2018; Direvisi: 10 April 2018; Disetujui: 29 April 2018

\begin{abstract}
The research aims to develop assessment curriculum on Technical Substantive Training of Curriculum 2013 for islamic secondary schools science teachers in Central-Java Province and Special-Region Yogyakarta using the qualitative method. The research shows that: a) the assessment component in lesson plan before the development from the lowest to the highest scores are indicator, key/criteria, scoring formula, instrumen, and assessment technique, $b$ ) the teacher weakness causes are the low mastery on some basic assessment materials (the assessment concept of the Curriculum 2013, analysis of the curriculum, mastery of operational working words, the skill to make criteria); c) the development of training curriculum on assessment concept, curriculum analysis, and lesson plan materials. The strategy is adding column of question indicators, technique, and assessment forms on the curriculum analyzes worksheet, assignment of higher order thinking skills indicators, and peer assessment.
\end{abstract}

Keywords: Assessment; Curriculum development; Lesson plan; Technical substantive training for teacher

\begin{abstract}
Abstrak
Tujuan penelitian adalah mengembangkan kurikulum diklat materi penilaian pembelajaran Diklat Teknis Substantif Kurikulum 2013 bagi guru IPA madrasah tsanawiyah di Jawa Tengah dan D.I Yogyakarta, metode kualitatif. Hasil penelitian adalah a) pencermatan komponen penilaian pada Rencana Pelaksanaan Pembelajaran (RPP) Guru sebelum pengembangan dari nilai terendah ke tertinggi: indikator soal, kunci/kriteria, rumus penskoran, instrumen penilaian, dan teknik penilaian; b) penyebab kelemahan guru adalah penguasaan materi yang masih rendah pada materi yang mendasari penilaian pembelajaran (konsep penilaian Kurikulum 2013, analisis kurikulum, penguasaan kata kerja operasional, dan keterampilan menyusun kriteria pada jenis penilaian nontes); dan c) pengembangan kurikulum diklat adalah pada mata diklat Penilaian Kurikulum 2013; Analisis Kurikulum, dan Praktik Penyusunan RPP. Strategi penyampaian dengan menambahkan kolom indikator soal, teknik, dan bentuk penilaian pada lembar kerja analisis kurikulum, penugasan sebagian indikator HOTS, dan koreksi produk sesama peserta.
\end{abstract}

Kata kunci: Diklat teknis substantif guru; Penilaian; Rencana pelaksanaan pembelajaran; Pengembangan kurikulum 


\section{PENDAHULUAN}

Guru adalah pendidik profesional dengan tugas utama mendidik, mengajar, membimbing, mengarahkan, melatih, menilai, dan mengevaluasi siswa pada pendidikan anak usia dini jalur pendidikan formal, pendidikan dasar, dan pendidikan menengah. ${ }^{1}$ Salah satu kewajiban guru adalah "dalam melaksanakan tugas keprofesionalan, guru berkewajiban merencanakan pembelajaran, melaksanakan proses pembelajaran yang bermutu, serta menilai dan mengevaluasi hasil pembelajaran."2 Berdasarkan ini, tugas guru adalah merencanakan, melaksanakan, dan mengevaluasi pembelajaran. Setiap guru hendaknya dapat melaksanakan penilaian yang sesuai dengan perencanaan dan pelaksanaan pembelajaran.

Sistem pembelajaran terdiri atas masukan, proses, dan keluaran. Siswa mengalami proses pembelajaran oleh guru. Untuk mengetahui keberhasilan proses dan ketercapaian tujuan dilakukan penilaian pembelajaran. Hasil penilaian digunakan untuk pengambilan berbagai keputusan. Ketidakmampuan guru melaksanakan penilaian dengan baik akan berakibat buruk. Hasil penilaian yang diperoleh dari teknik penilaian yang tidak sesuai, tidak dapat menggambarkan kompetensi siswa. Teknik penilaian untuk setiap aspek penilaian berbeda-beda menyesuaikan dengan kompetensi yang dinilai. ${ }^{3}$ Lebih lanjut, guru dapat memilih teknik penilaian yang paling sesuai dengan karakteristik kompetensi dasar, indikator, atau tujuan pembelajaran yang akan dinilai. ${ }^{4}$ Dengan demikian, setiap guru dituntut mampu menentukan teknik yang sesuai dengan indikator atau tujuan pembelajaran. Dengan teknik penilaian yang sesuai maka guru dapat

${ }^{1}$ Republik Indonesia. 2008. Peraturan Pemerintah Nomor 74 Tahun 2008 tentang Guru Pasal 1 dan Undang-undang Nomor 14 Tahun 2005 tentang Guru dan Dosen Pasal 1. Jakarta: Sekretariat Negara.

${ }^{2}$ Republik Indonesia. 2005. Undang-undang Nomor 14 Tahun 2005 tentang Guru dan Dosen Pasal 20. Jakarta: Sekretariat Negara.

${ }^{3}$ Republik Indonesia. 2016 b. Peraturan Menteri Pendidikan dan Kebudayaan Nomor 23 Tahun 2016 tentang Standar Penilaian Pendidikan. Jakarta: Kementerian Pendidikan dan kebudayaan, h. 7.

${ }^{4}$ Republik Indonesia. 2017 c. Panduan Penilaian Sekolah Menengah Pertama. Jakarta: Kementerian Pendidikan dan Kebudayaan, h. 61. menilai siswa berdasarkan kompetensi yang akan dicapai dan mendapatkan hasil penilaian sesuai dengan tujuannya.

Implementasi Kurikulum 2013 dilaksanakan secara bertahap pada setiap jenjang pendidikan dasar dan menengah sejak tahun 2013. Evaluasi terhadap guru Sekolah Menengah Pertama (SMP) ditemukan masih mengalami kesulitan dalam mengimplementasikan Kurikulum 2013. Hal yang sama juga dimungkinkan terjadi pada guru MadrasahTsanawiyah (MTs).

Hasil monitoring dan evaluasi pelaksanaan Kurikulum 2013 tingkat SMP pada 2014 menunjukkan salah satu kesulitan pendidik dalam mengimplementasikan Kurikulum 2013 adalah dalam melaksanakan penilaian. Sekitar $60 \%$ responden pendidik menyatakan, mereka belum dapat merancang, melaksanakan, mengolah, melaporkan, dan memanfaatkan hasil penilaian dengan baik. Salah satu kesulitan utama adalah mereka kurang percaya diri dalam melaksanakan penilaian keterampilan karena belum memahami penyusunan instrumen dan rubrik penilaian keterampilan. Selain itu, mereka juga belum percaya diri mengembangkan butir-butir soal pengetahuan. Butir-butir soal untuk pengetahuan faktual, konseptual, prosedural, dan metakognitif yang dikombinasikan dengan keterampilan berpikir tingkat rendah hingga tinggi. ${ }^{5}$

Guru yang melaksanakan penilaian dengan baik, hakikatnya berupaya melaksanakan perintah Allah Swt. Terjemahan QS. AlIsraa', 35: "Dan sempurnakanlah takaran apabila kamu menakar, dan timbanglah dengan neraca yang benar. Itulah yang lebih utama (bagimu) dan lebih baik akibatnya."6 Berdasarkan ayat ini, setiap guru hendaknya melaksanakan penilaian dengan benar agar hasilnya dapat dijadikan alat pengambil keputusan yang tepat.

Hasil penilaian yang baik dimulai dari perencanaan penilaian yang baik pula. Dalam implementasi Kurikulum 2013, kegiatan penilaian dimulai dari menganalisis Kompetensi Inti (KI) dan Kompetensi Dasar (KD) untuk

${ }^{5}$ Republik Indonesia. Panduan Penilaian Sekolah Menengah Pertama. h. 1.

${ }^{6}$ Tim. 1989. Al-Qur'an dan Terjemahan. Semarang: CV Thoha Putera. 
aspek pengetahuan, keterampilan, dan sikap; menyusun indikator; menetapkan teknik penilaian yang sesuai; menyusun instrumen penilaian; menetapkan kriteria untuk instrumen non tes dan kunci untuk instrumen tes; dan menetapkan penskorannya. Tuntutan Kurikulum 2013 untuk aspek pengetahuan merupakan kombinasi keterampilan berpikir tingkat rendah hingga tinggi. ${ }^{7}$ uru hendaknya memiliki kompetensi penilaian mengelola keterampilan berpikir tingkat tinggi (higher ordered thinking skills/HOTS). Dengan HOTS dapat mendorong siswa berpikir secara luas dan mendalam tentang konten mata pelajaran. Shepard (2000), reformasi dalam penilaian berfokus pada HOTS dan pemahaman mendalam. ${ }^{8}$

Perencanaan penilaian tertuang dalam RPP. Kenyataan, masih banyak ditemukan guru yang mengalami kesulitan tentang penilaian. Salah satu indikasinya adalah banyaknya permintaan madrasah dan kelompok guru untuk mengadakan diklat tentang penilaian pembelajaran. Kemampuan guru yang masih kurang dalam komponen penilaian dapat ditingkatkan melalui pengembangan kompetensi yang diselenggarakan oleh lembaga kediklatan. Salah satu kompetensi yang dikembangkan bagi guru adalah kompetensi teknis. "Pengembangan kompetensi teknis dapat dilaksanakan melalui pendidikan dan atau pelatihan."

Perkembangan ilmu pengetahuan dan teknologi yang pesat, memungkinkan terjadi perubahan tuntutan kompetensi dan kebutuhan diklat peserta yang berpengaruh pada penyelenggaraan pembelajaran diklat. Perubahan kurikulum dalam proses pembelajaran diklat merupakan keniscayaan sebagai bentuk adaptasi atas perubahan yang

\footnotetext{
${ }^{7}$ Republik Indonesia. Panduan Penilaian Sekolah Menengah Pertama, h. 2.

${ }^{8}$ L.A. Shepard, L.A. 2000. The Role of Classroom Assessment in Teaching and Learning. CSE Technical Report 517, Center for the Study of Evaluation National Center for Research on Evaluation, Standards, and Student Testing, Graduate School of Education and Information Studies, University of California, h. 36 .

${ }^{9}$ Republik Indonesia. 2017 d. Peraturan Pemerintah Nomor 11 Tahun 2017 tentang Manajemen PNS. Jakarta: Pasal 210 ayat 2:
}

terjadi di masyarakat. Widyaiswara hendaknya dapat menyesuaikan diri dengan melaksanakan pembelajaran yang dapat memenuhi kebutuhan dan mengembangkan kurikulum diklat.

Hasil pencermatan digunakan sebagai bahan untuk mengembangkan Kurikulum Diklat Materi Penilaian pada Diklat Kurikulum 2013. Secara ideal, desain program diklat dapat dikembangkan secara sistematik berdasarkan model desain pelatihan yang dikenal sebagai ADDIE (analysis, design, development, implementation, evaluation). ${ }^{10}$ Kelima tahapan di atas merupakan siklus yang dapat berulang dan masing-masing tahap dapat berulang kembali ke tahap sebelumnya. Dengan demikian kurikulum diklat bersifat terbuka untuk dikembangkan. ${ }^{11}$

Berdasarkan uraian di atas, penulis tertarik untuk menganalisis informasi tentang hasil pencermatan komponen penilaian pada RPP guru IPA MTs sesuai penilaian pembelajaran Kurikulum 2013; kelemahan guru IPA MTs dalam menyusun komponen penilaian pada RPP; dan penyebab kelemahan guru IPA MTs dalam menyusun komponen penilaian pada RPP; dan mengembangkan kurikulum materi penilaian pembelajaran pada Diklat Kurikulum 2013 bagi guru IPA madrasah tsanawiyah.

Penelitian ini bermanfaat bagi peserta diklat, peneliti, widyaiswara, dan pengambil kebijakan diklat. Peserta diklat dapat menggunakan pengembangan kurikulum materi penilaian untuk meningkatkan kompetensi pedagogik guru dalam bidang penilaian. Peneliti dapat melakukan pencermatan terhadap komponen penilaian pada RPP guru mata pelajaran IPA MTs dan menggunakannya sebagai acuan pengembangan Kurikulum Diklat. Widyaiswara dapat menggunakan hasil penelitian ini dalam pembelajaran materi penilaian pembelajaran. Pimpinan lembaga kediklatan sebagai pengambil kebijakan diharapkan memperoleh masukan berharga dalam memperkaya kurikulum diklat yang

\footnotetext{
${ }^{10}$ S. Kurt. 5 Mei 2018. Citing Internet Sources URL https://educationaltechnology.net/the-addie-modelinstructional-design/

${ }^{11}$ N. Aldoobie. 2015. ADDIE Model. American International Journal of Contemporary Research, 5 (6): h. 68-71.
} 
berbasis pada analisis kebutuhan peserta diklat materi penilaian pembelajaran.

Terkait dengan kemampuan guru dalam penilaian pembelajaran, telah dilakukan penelitian tentang perlunya penilaian formatif pembelajaran (penilaian pada setiap materi) yang memenuhi standar. ${ }^{12}$ Perbaikan penilaian yang ditawarkan adalah melalui teacher development, yaitu pembentukan kelompok sekolah yang berdekatan. ${ }^{13}$ Artikel Penulis berbeda dengan penelitian tersebut dalam pengembangan hasil penelitian yang berfokus pada perbaikan kurikulum.

Telah dilakukan penelitian yang berfokus pada pengujian pengaruh evaluasi pada aspek kognitif dan aspek sikap tertentu (kecemasan, efikasi diri, motivasi intrinsik, penyebab kesuksesan, penyebab kegagalan, dan kerjasama antar siswa). ${ }^{14}$ Penulis mencermati semua aspek penilaian meliputi pengetahuan, keterampilan sesuai kompetensi dasarnya dan aspek sikap sesuai dengan kompetensi intinya. Sikap tersebut adalah jujur, disiplin, tanggungjawab, santun, peduli, toleransi, dan percaya diri.

\section{Penilaian}

Penilaian adalah proses pengumpulan dan pengolahan informasi untuk mengukur pencapaian hasil belajar siswa. ${ }^{15}$ Penilaian adalah proses penggambaran, memperoleh, dan memberikan informasi yang berguna sebagai alternatif pengambilan keputusan. ${ }^{16}$ Dengan demikian, penilaian merupakan kegiatan untuk mengetahui keadaan sesuatu yang diukur atau diamati dengan prosedur tertentu untuk pengambilan keputusan. Dalam penilaian terdapat unsur proses pengumpulan informasi,

${ }^{12}$ P. Black \& Wiliam, D. 1998. Inside the Black Box: Raising Standards through Classroom Assessment. Phi Delta Kappa, October: 1-13: h. 1-2.

${ }^{13}$ P. Black \& Wiliam, D. Inside the Black Box: Raising Standards through Classroom Assessment. h. 10.

${ }^{14}$ T. Crooks. 1988. The Impact of Classroom Evaluation Practices on Students. Review of Educational Research, 58 (4): h. 470.

${ }^{15}$ Republik Indonesia. Peraturan Menteri Pendidikan dan Kebudayaan Nomor 23 Tahun 2016 tentang Standar Penilaian Pendidikan Pasal 1. h. 5.

${ }^{16}$ L.E. Cronbach. 1990. Essentials of Psychological Testing. New York: Harper and Row, h. 3. pengolahan informasi, dan kegiatan memanfatkan informasi.

Penilaian pembelajaran merupakan salah satu pilar dalam pelaksanaan kurikulum berbasis kompetensi sehingga harus dikuasai dengan baik oleh guru sesuai kurikulum yang berlaku. Kemampuan tersebut adalah memahami tujuan kurikulum; kemampuan menjabarkan tujuan kurikulum menjadi tujuan yang lebih spesifik; dan kemampuan untuk menterjemahkan tujuan khusus kepada kegiatan pembelajaran. ${ }^{17}$ Guru berkewajiban (1) stating clearly the instructional objectives of each course they teach; (2) directing their instruction toward the fulfillment of those objectives; and (3) designing their examinations to be consistent with these objectives. $^{18}$ Agar penilaian berhasil, guru hendaknya menyelaraskan penilaian dengan kegiatan dan tujuan pembelajaran.

\section{Rencana Pelaksanaan Pembelajaran (RPP)}

Setiap guru wajib menyusun RPP. RPP adalah rencana kegiatan pembelajaran tatap muka untuk satu pertemuan atau lebih. RPP berguna untuk mengarahkan kegiatan pembelajaran siswa agar mencapai Kompetensi Dasar (KD). ${ }^{19}$

Komponen RPP sebagai berikut, (1) Identitas Sekolah; (2) Identitas Mata Pelajaran; (3) Kelas/Semester; (4) Materi Pokok; (5) Alokasi Waktu; (6) Tujuan Pembelajaran; (7) Kompetensi Dasar dan Indikator Pencapaian Kompetensi; (8) Materi Pembelajaran; (9) Metode Pembelajaran; (10) Media pembelajaran; (11) Sumber Belajar; dan (12) Langkah-langkah Pembelajaran; dan (13) Penilaian Hasil Pembelajaran. ${ }^{20}$ Penilaian pembelajaran merupakan salah satu komponen yang terdapat dalam RPP. "Mekanisme penilaian hasil belajar oleh pendidik dilakukan

\footnotetext{
${ }^{17}$ Rusman. 2009. Manajemen Kurikulum. Jakarta: Rajawali Pers, h. 75-76.

${ }^{18}$ W.A. Mehrens \& I.J. Lehman. 1984. Measurement and Evaluation in Education and Psychology. ed. ke-3. Michigan: Holt, Rinehart and Winston, Inc., h. 19.

${ }^{19}$ Republik Indonesia. 2016a. Peraturan Menteri Pendidikan dan Kebudayaan Nomor 22 Tahun 2016 tentang Standar Proses Pendidikan Dasar dan Menengah. Jakarta: Kementerian Pendidikan dan Kebudayaan, h. 6.

${ }^{20}$ Ibid., h. 6-7.
} 
pada saat penyusunan RPP berdasarkan silabus."21

\section{Pengembangan Kurikulum Diklat}

Kurikulum merupakan suatu cara untuk mempersiapkan anak agar berpartisipasi sebagai anggota yang produktif dalam masyarakatnya. Setiap kurikulum paling tidak memiliki komponen tertentu, yaitu pernyataan tentang tujuan dan sasaran, seleksi dan organisasi bahan dan isi pelajaran, bentuk dan kegiatan belajar dan mengajar, dan evaluasi hasil belajar. $^{22}$ Kurikulum sebagai a plan for providing sets of learning opportunities for persons to be educated. ${ }^{23}$ Kurikulum merupakan bahan-bahan yang disiapkan dalam kegiatan kegiatan pembelajaran untuk membentuk siswa yang kompeten. Kurikulum dapat sebagai kumpulan materi, pengalaman belajar, tujuan, perencanaan pembelajaran, dan sistem evaluasi. Sebagai perencanaan, kurikulum belum bermanfaat jika belum diimplementasikan dalam pembelajaran. Pengembangan kurikulum berdasarkan tiga hal, yaitu masyarakat, pembelajar, dan ilmu pengetahuan. Kurikulum yang telah ada sangat terbuka untuk berubah menyesuaikan dengan perkembangan yang berlangsung.

The training is highly organized based on an education system and a curriculum which introduces different concepts at different times, exploiting previously learned concepts to ease the learning of new abstractions. "24 Materi diklat disesuaikan dengan sistem pendidikan yang berlaku, penguasaan konsep sebelumnya sangat penting untuk memudahkan penguasaan konsep yang baru. Pengembangan kurikulum dapat berupa penyusunan kurikulum itu sendiri, pelaksanaan kurikulum di sekolah/

${ }^{21}$ Republik Indonesia. Peraturan Menteri Pendidikan dan Kebudayaan Nomor 23 Tahun 2016 tentang Standar Penilaian Pendidikan Pasal 9, h. 7.

${ }^{22}$ S. Nasution. 2006. Asas-asas Kurikulum. ed. ke-2. cet. ke-7. Jakarta: Bumi Aksara, h. 7.

${ }^{23}$ J.G. Saylor, W.M. Alexander, A.J. Lewis. 1981. Curriculum Planning for Better Teaching and Learning. ed. ke-4. Nebraska: Holt, Rinehart and Winston, h. 9.

${ }^{24}$ Y. Bengio, J. Louradour, R. Collobert, \& J. Weston. 2009. Curriculum Learning. In Proceedings of the $26^{\text {th }}$ International Conference on Machine Learning. Montreal, Canada: Queen Mary, University of London. Citing Internet Sources. URL. https://qmro.qmul.ac.uk/xmlui/handle/123456789/15972 ., h. 2 . madrasah dengan penilaian yang intensif, dan penyempurnaan yang dilakukan terhadap komponen tertentu dari kurikulum berdasarkan hasil penilaian tersebut. ${ }^{25}$

Kurikulum diklat teknis sesuai dengan tuntutan jabatan. Kurikulum Diklat Teknis Substantif menekankan pada penguasaan kompetensi persyaratan standar kompetensi jabatan. Dalam diklat teknis substantif tidak hanya berupaya memberikan pemahaman suatu konsep kepada peserta diklat, melainkan juga memberikan kesempatan kepada peserta diklat untuk mempraktikkan keterampilan tertentu yang bermanfaat di tempat tugas. Kurikulum Diklat Teknis di lingkungan Kementerian Agama disusun oleh Badan Litbang dan Diklat. $^{26}$

\section{Diklat Teknis Substantif Guru}

Diklat (pendidikan dan pelatihan) diselenggarakan oleh lembaga diklat pemerintah dan dilaksanakan oleh widyaiswara. $^{27}$ Widyaiswara adalah pejabat yang mempunyai ruang lingkup tugas, tanggungjawab, wewenang, dan hak untuk melakukan kegiatan mendidik, mengajar, melatih PNS (yang selanjutnya disingkat dikjartih PNS), Evaluasi dan Pengembangan. Diklat yang dimaksud adalah kegiatan dikjartih yang merupakan proses belajar mengajar dalam diklat baik secara klasikal dan atau non klasikal. $^{28}$

Peningkatan kompetensi bagi setiap aparatur sipil negara merupakan keniscayaan. Melalui diklat diharapkan terbentuk PNS yang profesional. Syarat PNS yang profesional, yaitu adanya kesesuaian antara kemampuan

\footnotetext{
${ }^{25}$ H. Soetopo \& W. Soemanto. 1982. Pembinaan dan Pengembangan Kurikulum. Jakarta: Penerbit Bina Aksara, h. 45.

${ }^{26}$ Republik Indonesia. 2017b. Surat Keputusan Kepala Badan Litbang dan Diklat Kementerian Agama Republik Indonesia Nomor 62 Tahun 2017 tentang Struktur Kurikulum Pendidikan dan Pelatihan Tenaga Teknis Pendidikan dan Keagamaan Pusdiklat Tenaga Teknis Pendidikan dan Keagamaan. Jakarta: Badan Litbang dan Diklat..

${ }^{27}$ Republik Indonesia. 2014. Peraturan Menteri Negara Pendayagunaan Aparatur Negara dan Reformasi Birokrasi Nomor 22 Tahun 2014 tentang Jabatan Fungsional Widyaiswara dan Angka Kreditnya Pasal 1 Ayat 2.Jakarta: Kemenneg PAN \& RB.

${ }^{28}$ Ibid. Pasal 1 Ayat 4.
} 
aparatur dengan kebutuhan tugas. ${ }^{29}$ Dengan demikian, praktik dalam diklat memiliki porsi yang lebih besar daripada teori. Kebutuhan peserta diklat adalah mengimplementasikan konsep dalam penyelesaian tugas sehari-hari. Diklat sebagai proses pembelajaran dalam organisasi yang mengarah pada perubahan sikap dan perilaku pegawai memenuhi harapan kualifikasi kerja dan tuntutan perkembangan organisasi baik internal maupun eksternal. ${ }^{30}$ Diklat adalah suatu proses untuk meningkatkan pengetahuan, sikap, dan keterampilan pegawai dalam suatu organisasi untuk menciptakan sumber daya manusia yang profesional sesuai dengan tuntutan organisasi.

Guru dituntut memiliki kompetensi teknis yang handal dalam melaksanakan tugas. Tujuan pelaksanaan pelatihan teknis adalah untuk mencapai persyaratan standar kompetensi jabatan dan pengembangan karier. ${ }^{31}$ Diklat adalah salah satu bentuk pengembangan kompetensi di lingkungan Kementerian Agama. Diklat adalah penyelenggaraan pembelajaran dan pelatihan dalam rangka mengembangkan kompetensi pegawai sesuai persyaratan jabatan masing-masing, dilaksanakan paling sedikit 40 jam pelajaran dengan durasi setiap jam pelajaran adalah 45 menit. ${ }^{32}$

\section{METODE PENELITIAN}

Pendekatan penelitian ini adalah kualitatif dengan metode deskriptif. Dilakukan pengamatan terhadap fakta-fakta hasil pencermatan RPP guru IPA tanpa diberikan perlakuan apa pun. Data diperoleh secara natural dari kegiatan di madrasah dan di luar madrasah. In education, qualitative research is frequently called naturalistic because the

${ }^{29}$ W.A. Nurhajati \& B.S. Bachri. Pengembangan Kurikulum Pendidikan dan Pelatihan (Diklat) Berbasis Kompetensi dalam Membangun Profesionalisme Pegawai Negeri Sipil (PNS), h. 163.

${ }^{30}$ Rosidah. 6 April 2017. Citing Internet Sources. URL

http://staffnew.uny.ac.id/upload/131844875/penel itian/manajemen+diklat.pdf.

${ }^{31}$ Republik Indonesia. 2017 d. Peraturan Pemerintah Nomor 11 Tahun 2017 tentang Manajemen PNS Pasal 214 Ayat 2. Jakarta: Sekretariat Negara.

${ }^{32}$ Republik Indonesia. 2015. Peraturan Menteri Agama Nomor 75 Tahun 2015 tentang Penyelenggaraan Pendidikan dan Pelatihan Pegawai pada Kementerian Agama Pasal 1. Jakarta: Kementerian Agama. researcher hangs around where the eventshe or she is interested in naturally occur. ${ }^{33}$

Penelitian dilaksanakan di wilayah kerja BDK Semarang meliputi Provinsi Jawa Tengah dan D.I Yogyakarta. Waktu penelitian adalah Februari 2017 sampai Oktober 2018. Penetapan peserta berdasarkan analisis kebutuhan diklat di setiap kabupaten/kota. Kurikulum diklat yang dikembangkan adalah Kurikulum Diklat Penilaian Pembelajaran/ Penilaian Autentik. Pengumpulan data melalui pencermatan dokumen, kuesioner, pengamatan, dan wawancara. Analisis data dilakukan secara kualitatif, temuannya tidak diperoleh melalui prosedur statistik atau bentuk hitungan lainnya. ${ }^{34}$ Data angka yang diperoleh divisualisasi dalam diagram untuk memudahkan perbandingan antar komponen. "The word qualitative implies an emphasis on processes and meanings that are not rigorously examined." $" 35$ Analisis kualitatif dilakukan terhadap dokumen RPP Guru IPA MTs yang diberikan skala 1-4 (dari derajat tidak memenuhi ke sangat memenuhi). Salah satu instrumen kualitatif yang dapat digunakan adalah lembar pengamatan. ${ }^{36}$ Analisis meliputi penyusunan indikator soal pada masing-masing aspek, penetapan teknik, penyusunan instrumen, penetapan kunci/kriteria, dan penskorannya. Kriteria analisis penilaian ditetapkan berdasarkan Peraturan Menteri Pendidikan dan Kebudayaan Nomor 23 Tahun 2016 dan Panduan Penilaian SMP Tahun 2017.

\section{HASIL}

\section{Hasil Pencermatan Komponen Penilaian RPP Guru IPA MTs sesuai Penilaian Pembelajaran Kurikulum 2013}

${ }^{33}$ R.C. Bogdan \& S.K. Biklen. 1982. Qualitative Research. Washington: Allyn and Bacon, Inc., h. 3.

${ }^{34}$ A. Strauss \& J. Corbin. 2009. Dasar-dasar Penelitian Kualitatif: Tatalangkah dan Teknik-teknik Teoritisasi Data.cet. ke-3. Yogyakarta: Pustaka Pelajar, h. 4 .

${ }^{35}$ N.K. Denzin, N.K. \& Y.S. Lincoln, Y.S. 1994. Handbook of Qualitative Research. California: SAGE Publication, Inc., h. 4.

${ }^{36}$ J.W. Creswell. 2010. Research Design: Pendekatan Kualitatif, Kuantitatif, dan Mixed. (Terj. Achmad Fawaid). Judul Asli: Research Design: Qualitative, Quantitative, and Mixed Methods Approaches. Yogyakarta: Pustaka Pelajar, h. 267-270. 
Rata-rata hasil pencermatan terhadap lima komponen penilaian pada RPP guru IPA MTs adalah 2,824. Rata-rata komponen dari urutan tertinggi adalah komponen teknik penilaian, instrumen penilaian, rumus penskoran, kunci/kriteria, dan indikator soal seperti terdapat pada Gambar 1.

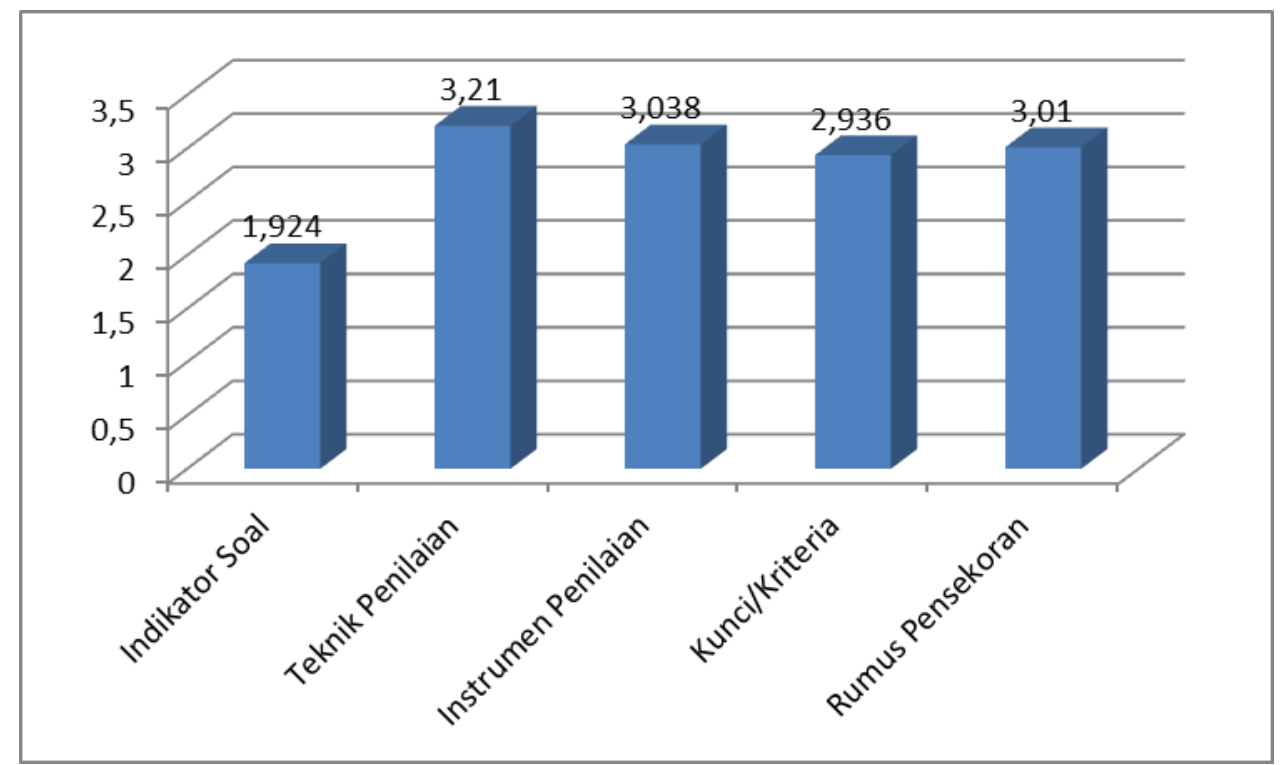

Gambar 1. Rata-rata hasil pencermatan RPP guru IPA MTs

\section{Rangkuman Hasil Kuesioner Peserta Diklat IPA MTs tentang Komponen Penilaian pada RPP}

Kuesioner diberikan kepada tiga puluh lima guru IPA MTs diperoleh hasil berikut.

1) Proses Penyusunan Komponen Penilaian dalam RPP

Semua guru membuat RPP sebagai kelengkapan administrasi pembelajaran. Delapan guru menyusun RPP secara mandiri dengan menggunakan aturan sesuai regulasi RPP. Mereka adalah guru yang pernah mengikuti diklat, workshop, atau mengikuti sosialisasi RPP. Dua puluh tiga guru membuat RPP dalam kelompok guru (bersama teman satu madrasah, MGMP). Lima belas guru hanya mengganti identitas, dan sisanya delapan guru melakukan modifikasi sesuai kebutuhan dan kondisi madrasah. Terdapat empat guru mengadaptasi dari RPP yang ada di Internet dengan mengganti komponen identitas.

2) Kesulitan dalam Menyusun Komponen Penilaian

Kesulitan peserta dalam komponen penilaian meliputi penentuan kata kerja operasional (KKO) untuk menyusun indikator; penyusunan indikator pada aspek sikap; penyusunan indikator pada aspek keterampilan; penyusunan instrumen penilaian sikap; pembuatan soal HOTS; pembuatan kriteria pada instrumen penilaian non tes; dan konversi skor menjadi predikat dan lambang.

3) Materi Penilaian yang Diharapkan pada Diklat Kurikulum 2013

Materi penilaian yang diharapkan ada Diklat Kurikulum 2013 adalah Konsep Penilaian Pembelajaran dalam Kurikulum 2013; Penyusunan Indikator Pencapaian Kompetensi Aspek Pengetahuan, Keterampilan, dan Sikap (diberikan waktu yang lebih banyak untuk indikator soal aspek sikap); Praktik Penyusunan Instrumen; Penetapan Kriteria Ketuntasan Minimal; dan Pengolahan Nilai.

Pertanyaan yang sama juga diberikan kepada guru non IPA MTs dan diperoleh hasil yang sama. Rata-rata guru juga mengalami kesulitan dalam menyusun indikator yaitu menetapkan KKO yang tepat, menyusun indikator HOTS, mendorong kreativitas, menyusun kriteria pada penilaian non tes, dan mengkonversi skor menjadi nilai, predikat, dan lambang. Pencermatan terhadap RPP guru non IPA MTs juga ditemukan hasil yang relatif sama. Dengan demikian, identifikasi kelemahan guru IPA dapat digunakan dalam sebagai acuan pengembangan kurikulum materi penilaian pembelajaran. 


\section{Hasil Pengamatan Proses Pembelajaran Diklat Mata Diklat Penilaian}

Pengamatan terhadap proses pembelajaran dilakukan pada mata diklat Pengembangan Penilaian Pembelajaran selama enam jam pelajaran Diklat Teknis Fungsional Tenaga Kependidikan Peningkatan Kompetensi Guru Tingkat Menengah Angkatan I bagi Guru IPA MTs Tahun 2017.

\section{1) Kegiatan Pendahuluan}

Di awal pembelajaran, widyaiswara memberikan pengantar tentang kesesuaian antara Kompetensi Inti (KI), Kompetensi Dasar (KD), dan indikator. Kesesuaian ini berimplikasi pada kegiatan pembelajaran dan penilaiannya pada RPP. Ilustrasi dilakukan dengan menayangkan slide yang memuat KI, $\mathrm{KD}$, dan indikator. Peserta menanggapi dengan mengusulkan indikator lain sebagai pelengkap. Selain itu, peserta juga menanyakan tentang cara menyusun indikator sikap. Widyaiswara menjelaskan indikator dapat ditambahkan dengan memperhatikan kebutuhan dan tingkat kemampuan siswa. Indikator yang dibuat hendaknya minimal sama dengan kompetensi pada KD-nya. Selanjutnya, widyaiswara menyampaikan komponen RPP dengan penilaian sebagai salah satunya.

\section{2) Kegiatan Inti}

Widyaiswara menyampaikan konsep dasar penilaian. Salah satu prinsip penilaian adalah komprehensif (menyeluruh) yaitu penilaian yang dilakukan terhadap siswa meliputi aspek sikap spiritual, sikap sosial, pengetahuan, dan keterampilan. Penilaian sikap dilakukan terhadap siswa dengan berdasar pada semua siswa adalah baik. Penilaian yang sangat baik dan kurang baik dilakukan dengan mengamati kejadian ekstrim (luar biasa). Jika terdapat kejadian siswa melakukan hal yang sesuai dengan indikator sikap maka mendapatkan tambahan nilai, jika tidak sesuai maka mendapatkan pengurangan nilai. Contoh sikap ekstrim: tidak sholat zuhur dan mengganggu teman. Ketika pembelajaran, banyak peserta yang mengutarakan kesulitan dalam penilaian sikap. Widyaiswara menanggapi dengan memberikan ilustrasi berupa pengisian kejadian luar biasa ke dalam kolom penilaian teknik jurnal yang ditayangkan.
Selanjutnya, widyaiswara meminta peserta menjelaskan penilaian aspek pengetahuan dan keterampilan yang telah dilakukan selama ini. Peserta menjawab pertanyaan tentang teknik penilaian yang digunakan dan bagaimana mereka melakukan. Namun, ternyata mereka masih kesulitan dalam menyusun instrumen penilaian yang HOTS. Widyaiswara menjelaskan dengan mulai dari ciri-ciri penilaian HOTS dan memberikan contoh instrumennya yang berasal dari indikator yang HOTS pula.

Widyaiswara kemudian menjelaskan teknik penilaian aspek pengetahuan dan aspek keterampilan. Peserta menjawab beberapa pertanyaan yang diajukan oleh widyaiswara dengan benar. Namun, ketika ditanyakan tentang proses konversi penilaian dari skor menjadi nilai akhir, lambang, dan predikat terjadi perdebatan di antara peserta. Ternyata terdapat perbedaan regulasi yang diajukan acuan. Widyaiswara menyampaikan regulasi penilaian terbaru berdasarkan Permendikbud Nomor 23 Tahun 2016 dan Panduan Penilaian oleh Pendidik dan Satuan Pendidikan untuk Sekolah Menengah Pertama Tahun 2017.

Sesuai dengan tujuan pembelajaran mata diklat penilaian adalah peserta dapat menyusun komponen penilaian pada RPP. Widyaiswara segera membimbing peserta dengan memberikan tugas berupa analisis SKL, KI, dan KD untuk satu materi pokok yang selanjutnya dijabarkan dalam komponen penilaian di RPP.

Penilaian yang dibuat setiap kelompok dipresentasikan, didiskusikan, dan diperbaiki sesuai dengan masukan-masukan.

3) Kegiatan Penutup

Widyaiswara menyampaikan bahwa komponen penilaian bersama-sama dengan komponen lain disempurnakan sebagai produk Diklat Teknis Fungsional Tenaga Kependidikan Peningkatan Kompetensi Guru Tingkat Menengah Angkatan I bagi Guru IPA MTs Tahun 2017. Kelengkapan komponen lain sesuai dengan mata diklat, misal: komponen kegiatan pembelajaran pada mata diklat modelmodel pembelajaran.

\section{PEMBAHASAN}

Analisis Komponen Penilaian pada RPP Guru IPA MTs sesuai Penilaian Pembelajaran Kurikulum 2013 
Komponen indikator soal merupakan komponen prioritas yang memerlukan penanganan untuk diperbaiki. Hasil kerja guru dalam menyusun indikator soal paling rendah di antara komponen yang lain. Lebih lanjut berdasarkan data analisis terhadap komponen indikator soal, semua sub komponen menunjukkan hasil pencermatan yang rendah (skor 1,486-2,314).Rentang ini berada pada kriteria di bawah 3 (di bawah memadai). Grafik rata-rata hasil pencermatan terhadap sub komponen indikator soal sebagai berikut.

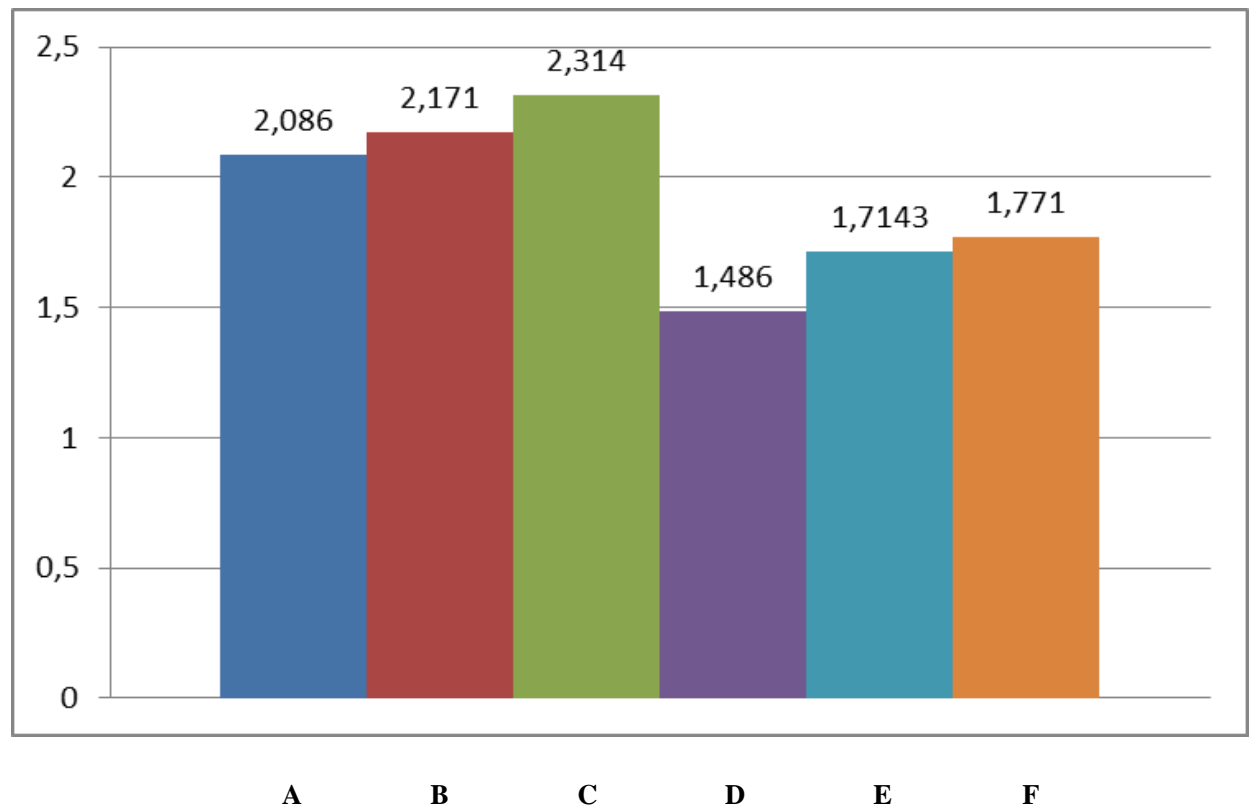

Gambar 2. Rata-rata hasil pencermatan terhadap sub komponen indikator soal

Keterangan:
A : Kesesuaian dengan kompetensi dasarnya
B : Memuat kata kerja operasional yang sesuai dengan aspek yang diukur
C : Mengukur secara hierarki pencapaian kompetensi KD
D : Mencakup level berfikir HOTS pada aspek pengetahuan (menganalisis, mengevaluasi, dan mencipta)
E : Mendorong kreativitas siswa
F : Menumbuhkan dan memperkuat karakter siswa

Semua sub komponen indikator soal, yaitu A, B, C, D, E, dan F memperoleh skor rendah. Tiga kelompok paling rendah adalah level berpikir HOTS, mendorong kreativitas siswa, dan menumbuhkan dan memperkuat karakter siswa. Ketiga hal di atas terkait dengan pembelajaran sesuai dengan Kurikulum 2013 dalam mata diklat Konsep Kurikulum 2013. Konsep Kurikulum 2013 mensyaratkan bahwa pembelajaran diarahkan pada tingkat berpikir tinggi. Peneliti memperhatikan KD yang masih berada pada level C-3 dijadikan alasan oleh guru untuk tidak membuatkan indikator soal HOTS. Padahal kompetensi pada KD merupakan kompetensi minimal yang hendaknya dicapai oleh siswa. Untuk KD yang telah mencapai level berpikir HOTS, guru belum menunjukkan kemampuan yang baik ketika menurunkannya menjadi indikator.

Rendahnya sub komponen $\mathrm{F}$ (menumbuhkan dan memperkuat karakter siswa), diperoleh melalui pencermatan indikator aspek keterampilan. Kegiatan keterampilan diharapkan dapat mendorong siswa memiliki sikap-sikap yang diperlukan sesuai dengan kegiatan yang dirancang guru, yaitu jujur, disiplin, tanggungjawab, peduli (toleransi, gotong royong), santun, dan percaya diri sesuai dengan sikap sosial pada KI.

\section{Analisis Kelemahan Guru dalam Penilaian dan Penyebabnya}

Berdasarkan hasil pencermatan RPP dan kuesioner guru IPA MTs diperoleh bahwa guru IPA MTs mengalami kesulitan penilaian 
pembelajaran dalam komponen indikator soal, kunci/kriteria, dan rumus penskoran.

1) Indikator Soal

a) Kesesuaian dengan kompetensi dasarnya

Indikator soal yang dibuat merujuk langsung pada indikator pencapaian kompetensi (IPK) nya. IPK adalah indikator yang dibuat oleh guru berdasarkan KD-nya. Indikator soal dapat sesuai dengan IPK, tanpa dilakukan perubahan. Namun, agar dapat mengkondisikan siswa berpikir HOTS dan kreatif disarankan indikator soal dapat memenuhi rumus $\mathrm{ABCD}$ atau $\mathrm{ABC}$ saja. Indikator soal yang ideal sesuai dengan rumus ABCD, yaitu A (audience), B (behaviour), $\mathrm{C}$ (condition), dan D (degree). Indikator soal yang sama dengan IPK berarti hanya memuat $\mathrm{A}$ dan $\mathrm{B}$, tanpa $\mathrm{C}$ dan $\mathrm{D}$.

b) Memuat kata kerja operasional (KKO) yang sesuai dengan aspek yang diukur/ diamati

Peserta masih menggunakan KKO pada aspek sikap yang tidak dapat diamati dengan pengamatan, melainkan penilaian diri dan atau penilaian antar teman seperti mengakui, menerima, meyakini, mempercayai, dan lain-lain kata kerja yang tidak dapat diamati dengan teknik pengamatan.

Selain itu, juga masih ditemukan penggunaan $\mathrm{KKO}$ aspek pengetahuan yang tidak operasional seperti memahami, menerangkan, mengenal, mengetahui, dan menentukan.

c) Mengukur secara hierarki pencapaian kompetensi KD

Indikator belum dibuat secara berurutan sesuai dengan tingkat kompetensi. Misal indikator pada aspek keterampilan hanya 1 (satu) langsung merujuk pada kompetensi dasarnya. $n$.

d) Mencakup level berfikir HOTS pada aspek pengetahuan (menganalisis, mengevaluasi, dan mencipta)

Indikator soal masih berada pada taraf berpikir rendah (bukan HOTS) yang ditunjukkan dengan penggunaan KKO-nya. Masih beranggapan bahwa
KKO yang bukan tingkat berpikir tinggi tidak dapat dibuatkan soal berpikir tingkat tinggi. Peserta belum membuat indikator soal HOTS pada $\mathrm{KD}$ yang kompetensinya di atas $\mathrm{C}-3$.

e) Mendorong kreativitas siswa

Konten indikator soal belum mendorong kreativitas siswa karena belum tampak stimulusnya. Penyusunan indikator soal yang dibuat masih sama dengan indikator pencapaian kompetensinya.

f) Menumbuhkan dan memperkuat karakter siswa

Indikator sikap dan indikator keterampilan belum sinkron saling mendukung penumbuhan dan penguatan karakter siswa.

\section{2) Kunci/Kriteria}

Masih terdapat kunci jawaban untuk tes uraian yang belum dirinci per batasan konten. Kunci masih secara global untuk satu nomor tersebut. Kriteria untuk non tes belum dirumuskan secara detail, masih bersifat umum, sehingga belum operasional.

\section{3) Rumus Penskoran}

Peserta masih berdebat tentang konversi skor ke nilai, lambang, dan predikat. Penggunaan istilah skor dan nilai yang belum konsisten. Masih adanya skor yang dikonversi ke nilai pada aspek sikap. Masih ditemukan kesalahan mengkonversi skor ke nilai. Rentang nilai yang kurang tepat untuk dikonversi menjadi lambang dan predikat.

Analisis terhadap faktor penyebab terhadap kelemahan guru dalam penilaian dilakukan dengan menganalisis penyebab terjadinya kelemahan guru dalam komponen penilaian RPP. Faktor penyebab yang dimaksudkan adalah materi yang diperlukan penguatan pemahaman agar dapat menguasai sub komponen yang lemah tersebut.

\section{Pengembangan Kurikulum Diklat Penilaian Pembelajaran}

Pengembangan diawali dengan pra pengembangan yang terdiri atas pencermatan RPP, identifikasi kelemahan guru dalam penilaian, pengamatan proses pembelajaran diklat mata diklat penilaian pembelajaran, 
analisis faktor penyebab, dan analisis diklat kelompok inti dan diklat Kurikulum kebutuhan.

A. Tahap pengembangan

Berdasarkan temuan dan pembahasan pada tahap pra pengembangan dibuat desain/rancangan pengembangan kurikulum pada diklat penilaian pembelajaran pada mata 2013 mata diklat Penilaian Autentik pada Kurikulum 2013.

a) Desain/rancangan pengembangan kurikulum

(1) Mata Diklat Inti pada Diklat Penilaian Pembelajaran (Tabel 2)

Tabel 1. Reduksi data kelemahan guru IPA, penyebab, dan analisis kebutuhan

\begin{tabular}{|c|c|c|c|}
\hline No. & $\begin{array}{l}\text { Sub komponen yang } \\
\text { lemah }\end{array}$ & Penyebab & Analisis kebutuhan \\
\hline 1. & $\begin{array}{l}\text { Kesesuaian dengan } \\
\text { kompetensi dasarnya }\end{array}$ & $\begin{array}{l}\text { Penguasaan analisis SKL, KI, dan } \\
\text { KD sesuai Kurikulum } 2013 \text { masih } \\
\text { perlu ditingkatkan }\end{array}$ & $\begin{array}{l}\text { Mengintensifkan praktik menyusun } \\
\text { indikator soal sesuai IPK-nya pada } \\
\text { setiap aspek sesuai Kurikulum } 2013\end{array}$ \\
\hline 2. & $\begin{array}{l}\text { Memuat kata kerja } \\
\text { operasional yang } \\
\text { sesuai dengan aspek } \\
\text { yang diukur }\end{array}$ & $\begin{array}{l}\text { Penguasaan KKO ketiga aspek } \\
\text { masih perlu ditingkatkan }\end{array}$ & $\begin{array}{l}\text { Mengintensifkan praktik penyusunan } \\
\text { indikator dengan KKO yang sesuai pada } \\
\text { setiap aspek sesuai Kurikulum } 2013\end{array}$ \\
\hline 3. & $\begin{array}{l}\text { Mengukur secara } \\
\text { hierarki pencapaian } \\
\text { kompetensi KD }\end{array}$ & $\begin{array}{l}\text { Penguasaan urutan KKO ketiga } \\
\text { aspek perlu ditingkatkan. } \\
\text { Penguasaan substansi materi masih } \\
\text { perlu ditingkatkan }\end{array}$ & $\begin{array}{l}\text { Mematangkan penguasaan hierarki } \\
\text { konsep materi yang dijadikan sebagai } \\
\text { dasar penyusunan indikator }\end{array}$ \\
\hline 4. & $\begin{array}{l}\text { Mencakup level } \\
\text { berfikir HOTS pada } \\
\text { aspek pengetahuan } \\
\text { (menganalisis, } \\
\text { mengevaluasi, dan } \\
\text { mencipta) }\end{array}$ & $\begin{array}{l}\text { Penguasaan konsep penilaian } \\
\text { pembelajaran sesuai Kurikulum } \\
2013 \text { masih perlu ditingkatkan }\end{array}$ & $\begin{array}{l}\text { Mematangkan konsep penilaian } \\
\text { pembelajaran sesuai Kurikulum 2013, } \\
\text { khususnya peningkatan HOTS }\end{array}$ \\
\hline 5. & $\begin{array}{l}\text { Mendorong kreativitas } \\
\text { siswa }\end{array}$ & $\begin{array}{l}\text { Penguasaan konsep pembelajaran } \\
\text { sesuai Kurikulum } 2013 \text { masih perlu } \\
\text { ditingkatkan }\end{array}$ & $\begin{array}{l}\text { Mematangkan konsep pembelajaran } \\
\text { sesuai Kurikulum 2013, khususnya } \\
\text { mendorong kreativitas }\end{array}$ \\
\hline 6. & $\begin{array}{l}\text { Menumbuhkan dan } \\
\text { memperkuat karakter } \\
\text { siswa }\end{array}$ & $\begin{array}{l}\text { Penguasaan konsep pembelajaran } \\
\text { sesuai Kurikulum } 2013 \text { masih perlu } \\
\text { ditingkatkan }\end{array}$ & $\begin{array}{l}\text { Mematangkan konsep pembelajaran } \\
\text { sesuai Kurikulum 2013, khususnya } \\
\text { penguatan karakter }\end{array}$ \\
\hline 7. & $\begin{array}{l}\text { Kunci/kriteria } \\
\text { dirumuskan dengan } \\
\text { benar }\end{array}$ & $\begin{array}{l}\text { Penguasaan membuat kriteria } \\
\text { penilaian perlu ditingkatkan untuk } \\
\text { jenis non tes }\end{array}$ & $\begin{array}{l}\text { Penyediaan waktu yang cukup untuk } \\
\text { praktik jenis penilaian non tes }\end{array}$ \\
\hline 8. & $\begin{array}{l}\text { Kebenaran konversi } \\
\text { skor ke nilai, lambang, } \\
\text { dan predikat }\end{array}$ & $\begin{array}{l}\text { Pemahaman konsep skor, nilai, } \\
\text { predikat, dan lambang perlu } \\
\text { ditingkatkan sesuai Panduan } \\
\text { Penilaian Kurikulum } 2013\end{array}$ & $\begin{array}{l}\text { Mematangkan konsep KKM } \\
\text { Mematangkan konsep skor, nilai, } \\
\text { predikat dan lambang sesuai Panduan } \\
\text { Penilaian Kurikulum } 2013\end{array}$ \\
\hline
\end{tabular}

Tabel 2. Kurikulum mata diklat kelompok inti pada diklat teknis substantif penilaian pembelajaran pra pengembangan

\begin{tabular}{|c|c|c|c|c|}
\hline \multirow{2}{*}{ No. } & \multirow{2}{*}{$\begin{array}{l}\text { Mata diklat kelompok } \\
\text { inti }\end{array}$} & \multirow{2}{*}{ Pokok bahasan (silabus) } & \multicolumn{2}{|c|}{ Jumlah Jp } \\
\hline & & & Teori & Praktik \\
\hline 1. & $\begin{array}{l}\text { Konsep penilaian } \\
\text { kurikulum } 2013\end{array}$ & $\begin{array}{l}\text { a. Pengertian penilaian autentik } \\
\text { b. Sistem penilaian kurikulum } 2013\end{array}$ & 4 & \\
\hline 2. & $\begin{array}{l}\text { Analisis penilaian sikap } \\
\text { dan keterpaduan KD-KD }\end{array}$ & $\begin{array}{l}\text { a. Sikap } \\
\text { b. Keterpaduan KD-KD } \\
\text { c. Memetakan sikap Keterpaduan KD-KD }\end{array}$ & 2 & 2 \\
\hline 3. & $\begin{array}{l}\text { Penilaian sikap dan } \\
\text { instrumen }\end{array}$ & $\begin{array}{l}\text { a. Membuat lembar observasi guru (rubrik) disertai penskoran dan } \\
\text { penilaian } \\
\text { b. Membuat penilaian diri (self evaluation) disertai penskoran dan } \\
\text { penilaian } \\
\text { c. Membuat penilaian antar teman (peer evaluation) disertai } \\
\text { penskoran dan penilaian } \\
\text { d. Membuat jurnal (anecdotal record) }\end{array}$ & 2 & 4 \\
\hline 4. & $\begin{array}{l}\text { Penilaian pengetahuan } \\
\text { dan instrumen }\end{array}$ & $\begin{array}{l}\text { Membuat instrumen penilaian pengetahuan, penskoran dan } \\
\text { penilaian }\end{array}$ & 2 & 5 \\
\hline
\end{tabular}




\begin{tabular}{|c|c|c|c|c|}
\hline \multirow{2}{*}{ No. } & \multirow{2}{*}{$\begin{array}{l}\text { Mata diklat kelompok } \\
\text { inti }\end{array}$} & \multirow{2}{*}{ Pokok bahasan (silabus) } & \multicolumn{2}{|c|}{ Jumlah Jp } \\
\hline & & & Teori & Praktik \\
\hline 5. & $\begin{array}{l}\text { Penilaian ketrampilan } \\
\text { dan instrumen }\end{array}$ & $\begin{array}{l}\text { a. Membuat instrumen penilaian praktik, penskoran dan penilaian } \\
\text { b. Membuat instrumen penilaian proyek, penskoran dan penilaian } \\
\text { c. Membuat instrumen penilaian portofolio, penskoran dan } \\
\text { penilaian }\end{array}$ & 2 & 5 \\
\hline 6. & $\begin{array}{l}\text { Pengolahan dan } \\
\text { pelaporan hasil penilaian }\end{array}$ & $\begin{array}{l}\text { a. Pengolahan nilai sikap } \\
\text { b. Pengolahan nilai pengetahuan } \\
\text { c. Pengolahan nilai ketrampilan } \\
\text { d. Pelaporan nilai sikap } \\
\text { e. Pelaporan nilai pengetahuan } \\
\text { f. Pelaporan nilai ketrampilan } \\
\text { g. Penyusunan laporan hasil belajar }\end{array}$ & 2 & 5 \\
\hline 7. & $\begin{array}{l}\text { Pelaporan hasil penilaian } \\
\text { elektronik }\end{array}$ & $\begin{array}{l}\text { a. Mengenal microsoft excel } \\
\text { b. Penggunaan menu mean, modus, max, if, vlookup, dan hlookup, } \\
\text { vba. }\end{array}$ & 2 & 4 \\
\hline & & Jumlah & 16 & 25 \\
\hline
\end{tabular}

Kurikulum di atas dikembangkan sesuai dengan usulan perbaikan berdasarkan kelemahan guru IPA MTs menjadi sebagai berikut.

Tabel 3. Kurikulum mata diklat kelompok inti pada diklat teknis substantif penilaian pembelajaran hasil pengembangan

\begin{tabular}{|c|c|c|c|c|}
\hline \multirow{2}{*}{ No. } & \multirow{2}{*}{$\begin{array}{l}\text { Mata diklat kelompok } \\
\text { inti }\end{array}$} & \multirow{2}{*}{ Pokok bahasan (silabus) } & \multicolumn{2}{|c|}{ Jumlah Jp } \\
\hline & & & Teori & Praktik \\
\hline 1. & $\begin{array}{l}\text { Konsep Penilaian } \\
\text { Kurikulum } 2013\end{array}$ & $\begin{array}{l}\text { a. Konsep Penilaian Pembelajaran } \\
\text { b. Penilaian Pembelajaran Kurikulum } 2013 \\
\text { c. Kriteria Ketuntasan Minimal (KKM) } \\
\text { d. Penilaian Pembelajaran dalam Rencana Pelaksanaan } \\
\text { Pembelajaran }\end{array}$ & 3 & 1 \\
\hline 2. & $\begin{array}{l}\text { Analisis Penilaian Sikap } \\
\text { dan Keterpaduan KD-KD }\end{array}$ & $\begin{array}{l}\text { a. Analisis SKL, KI, dan KD } \\
\text { b. Praktik Analisis SKL, KI, dan KD sesuai dengan RPP }\end{array}$ & 1 & 4 \\
\hline 3. & $\begin{array}{l}\text { Penilaian Sikap dan } \\
\text { Instrumen }\end{array}$ & $\begin{array}{l}\text { a. Teknik dan Bentuk Penilaian Aspek Sikap } \\
\text { b. Penyusunan Indikator Soal Aspek Sikap } \\
\text { c. Penyusunan Instrumen Sikap dan Kriterianyanya } \\
\text { d. Konversi Penskoran, Penilaian, Predikat, dan Lambang Aspek } \\
\text { Sikap }\end{array}$ & 2 & 6 \\
\hline 4. & $\begin{array}{l}\text { Penilaian Pengetahuan } \\
\text { dan Instrumen }\end{array}$ & $\begin{array}{l}\text { a. Teknik dan Bentuk Penilaian Aspek Pengetahuan } \\
\text { b. Penyusunan Indikator Soal Aspek Pengetahuan } \\
\text { c. Penyusunan Instrumen Pengetahuan dan Kunci Jawabannya } \\
\text { d. Konversi Penskoran, Penilaian, Predikat, dan Lambang Aspek } \\
\text { Pengetahuan }\end{array}$ & 2 & 4 \\
\hline 5. & $\begin{array}{l}\text { Penilaian Ketrampilan } \\
\text { dan Instrumen }\end{array}$ & $\begin{array}{l}\text { a. Teknik dan Bentuk Penilaian Aspek Keterampilan } \\
\text { b. Penyusunan Indikator Soal Aspek Keterampilan } \\
\text { c. Penyusunan Instrumen Pengetahuan dan Kriterianya } \\
\text { d. Konversi Penskoran, Penilaian, Predikat, dan Lambang Aspek } \\
\text { Keterampilan }\end{array}$ & 2 & 5 \\
\hline 6. & $\begin{array}{l}\text { Pengolahan dan } \\
\text { Pelaporan Hasil } \\
\text { Penilaian }\end{array}$ & $\begin{array}{l}\text { a. Pengolahan Nilai Sikap } \\
\text { b. Pengolahan Nilai Pengetahuan } \\
\text { c. Pengolahan Nilai Ketrampilan } \\
\text { d. Pelaporan Nilai Sikap } \\
\text { e. Pelaporan Nilai Pengetahuan } \\
\text { f. Pelaporan Nilai ketrampilan } \\
\text { g. Penyusunan Laporan Hasil Belajar }\end{array}$ & 1 & 7 \\
\hline 7 & $\begin{array}{l}\text { Pelaporan Hasil } \\
\text { Penilaian Elektronik }\end{array}$ & $\begin{array}{l}\text { a. Mengenal Microsoft Excel } \\
\text { b. Penggunaan menu mean, modus, max, IF, Vlookup, dan } \\
\text { Hlookup, VBA. }\end{array}$ & 1 & 2 \\
\hline & & Jumlah & 12 & 29 \\
\hline
\end{tabular}


Tabel 3 memuat pengembangan tujuh diklat inti pada Diklat Teknis Substantif Penilaian Pembelajaran. Pengembangan yang dilakukan tidak menambah jam total pelaksanaan tatap muka.

Pertama, mengusulkan materi tertentu yang berhubungan dengan mata diklat Konsep Penilaian Kurikulum 2013. Pengembangan yang dilakukan adalah menambahkan materi KKM dan penilaian pembelajaran dalam RPP. Materi KKM sangat penting disampaikan karena penilaian pembelajaran kurikulum 2013 revisi beracuan pada patokan/kriteria. Patokan ini berupa KKM yang dibuat oleh masingmasing satuan pendidikan. Dengan adanya KKM ini maka guru dapat menetapkan kedudukan setiap peserta dibandingkan dengan KKM berupa predikat (sangat baik, baik, cukup, atau kurang). Selanjutnya, materi penilaian dalam RPP diberikan pada materi pertama ini dengan tujuan menanamkan sejak awal kepada peserta bahwa dalam RPP terdapat komponen penilaian. Agar penilaian berhasil, hendaknya dilakukan persiapan penyusunan dokumen perencanaan pembelajaran.

Kedua, memperdalam per mata diklat. Pada mata diklat kedua, yaitu Analisis Penilaian Sikap dan keterpaduan KD-KD, penulis menerapkan strategi menyampaikan terlebih dahulu analisis SKL-KI-KD dengan tujuan agar secara komprehensif para guru dapat mencermati kaitan antar aspek (sikap, pengetahuan, dan keterampilan). Pada struktur kurikulum sebelum pengembangan, pembahasan analisis KI-KD dilakukan per aspek atau terpisah sesuai dengan jadual mata diklatnya. Hal ini menyebabkan pemahaman terhadap konsep penilaian pembelajaran yang autentik menjadi kurang mantap.

Ketiga, penambahan jam praktik terjadi pada mata diklat nomor $1,2,3$, dan 6. Jam praktik pengembangan menjadi $70 \%$ dari 61 $\%$ pada pra pengembangan. Mata diklat nomor 1 memerlukan adanya praktik pada materi KKM; mata diklat nomor 2 pada praktik analisis SKL-KI-KD; mata diklat nomor 3 pada praktik pembuatan indikator, instrumen, dan konversi nilai menjadi predikat pada aspek sikap; dan mata diklat nomor 6 pada praktik pengolahan dan pelaporan penilaian. Terjadi pengurangan jumlah jam pelajaran pada mata diklat nomor 4 dan 7. Mata diklat nomor 4 adalah penilaian pengetahuan dan instrumen. Asumsi penulis, peserta telah terbiasa menyusun instrumen penilaian pengetahuan. Waktu yang ada meskipun telah dikurangi, diarahkan untuk membuat indikator dan instrumen HOTS. Mata diklat nomor 7 terjadi pengurangan jam pelajaran untuk kajian mengenal microsoft excel dan penggunaan menu. Waktu 3 jam dialihkan untuk kegiatan praktik yang lebih penting pada mata diklat lain. Program microsoft excel telah dikenal hampir semua guru sehingga tidak diperlukan tatap muka yang lama.

Keempat, penerapan strategi tertentu tejadi karena adanya penambahan jam praktik. Widyaiswara membuat form yang diperlukan, seperti form SKL-KI-KD yang lebih praktis dan meminta peserta lebih mengaktifkan hubungan kolegial mutual antar peserta.

(2) Mata diklat penilaian autentik pada Kurikulum 2013

Mata diklat penilaian autentik adalah salah satu mata diklat inti pada Diklat Kurikulum 2013. Pokok bahasan sebelum pengembangan sesuai dengan kurikulum silabus adalah Konsep Penilaian; Penilaian Autentik; Contoh Instrumen Penilaian; dan Penerapan Penilaian autentik.

Desain pengembangan kurikulum mata diklat penilaian autentik pada Kurikulum 2013 adalah Konsep Penilaian Kurikulum 2013 (HO1TS, C-4); Jenis, Teknik, dan Bentuk Penilaian; Analisis SKL-KI-KD sesuai KD RPP; dan Praktik Penyusunan Komponen Penilaian pada RPP (Sikap, Pengetahuan, dan Keterampilan) meliputi teknik, bentuk, instrumen, penyusunan kunci jawaban/ kriteria, dan rumus penskoran.

\section{B. Focus Group Discussion (FGD)}

Telah dilakukan FGD yang dihadiri oleh para widyaiswara pengampu mata diklat penilaian pembelajaran. Kegiatan diawali dengan memberikan daftar pertanyaan tentang tanggapan terhadap pengembangan kurikulum yang diajukan.

Hasil FGD sebagai berikut.

(a) Diklat penilaian pembelajaran

Semua widyaiswara menyetujui penambahan waktu praktik sesuai pada Tabel 3. Penambahan waktu terdapat pada praktik 
terdapat pada mata Diklat Analisis Penilaian Sikap dan Keterpaduan KD-KD (semula 2 menjadi 4 jam pelajaran). Terdapat penambahan pokok bahasan materi pada beberapa mata diklat yang mendukung pemahaman mata diklat berikutnya. Misalnya: Pokok bahasan KKM pada mata diklat Konsep Penilaian Kurikulum 2013 yang memperkuat pada Pokok Bahasan Konversi Penskoran, Penilaian, Predikat, dan Lambang pada Mata Diklat Penilaian Sikap dan Instrumen, Penilaian Pengetahuan dan Instrumen, dan Penilaian Keterampilan dan Instrumen.

Disarankan untuk menambah pokok bahasan Aplikasi dan Praktik Pelaporan Elektronik.

(b) Penilaian Autentik pada Kurikulum 2013 Penyampaian konsep penilaian Kurikulum 2013 dilakukan dengan brainstorming, mengingat materi ini telah disampaikan detail pada mata diklat Konsep Kurikulum 2013. Ketika praktik analisis SKL, $\mathrm{KI}$, dan KD peserta diarahkan langsung pada KD RPP masing-masing kelompok/peserta. Lembar kerja analisis SKL, KI, dan KD ditambah kolom indikator soal dan teknikbentuk penilaian. Dalam pembuatan indikator, diarahkan untuk menyusun indikator HOTS. Disediakan waktu mempresentasikan hasil praktik setelah peserta menyusun RPP. Total waktu 8 jam pelajaran digunakan untuk teori 1 jam pelajaran dan praktik 7 jam pelajaran.

\section{Uji Coba}

Uji coba yang dilakukan adalah pada pembelajaran mata diklat Penilaian Autentik pada Kurikulum 2013. Tidak tersedia diklat penilaian pembelajaran pada kurun waktu uji coba. Dilakukan uji coba pada Diklat Kerjasama Kurikulum 2013 Edisi Revisi bagi Guru MTs se Kabupaten Jepara (30 Juli-2 Agustus 2017) dan se-Kabupaten Sukoharjo (2-6 Oktober 2017). Hasil uji coba menunjukkan desain kurikulum mata diklat penilaian autentik pada Kurikulum 2013 dapat diterapkan dan produk komponen penilaian pada RPP peserta menunjukkan lebih baik daripada sebelum mengikuti diklat.

D. Revisi

Berdasarkan FGD dan hasil uji coba dilakukan revisi terhadap pengembangan kurikulum mata diklat penilaian autentik pada Kurikulum 2013. Pokok bahasan pengembangan kurikulum adalah Konsep Penilaian Kurikulum 2013 (HOTS, C-4); Analisis SKL-KI-KD sesuai RPP; Jenis, Teknik, dan Bentuk Penilaian; Praktik Penyusunan Komponen Penilaian pada RPP; dan Presentasi Hasil Praktik RPP. Waktu pembelajaran sesuai dengan kurikulum adalah delapan jam pelajaran.

Berikut pokok bahasan mata diklat penilaian autentik dan hasil pengembangannya sesuai dengan hasil FGD dan uji coba.

Tabel 4. Daftar revisi pengembangan kurikulum penilaian pembelajaran

\begin{tabular}{|c|c|c|}
\hline No. & Pokok Bahasan & Teori/Praktik \\
\hline 1. & $\begin{array}{l}\text { Konsep Penilaian Kurikulum } 2013 \\
\text { (HOTS, C-4) }\end{array}$ & Teori (1 jam pelajaran) \\
\hline 2. & $\begin{array}{l}\text { Analisis SKL-KI-KD sesuai KD } \\
\text { RPP }\end{array}$ & $\begin{array}{l}\text { Praktik menggunakan lembar kerja yang kolomnya ditambah } \\
\text { indikator soal, dan teknik-bentuk penilaian sesuai aspek ( } 2 \text { jam }\end{array}$ \\
\hline 3. & $\begin{array}{l}\text { Jenis, Teknik, dan Bentuk } \\
\text { Penilaian }\end{array}$ & pelajaran) \\
\hline 4. & $\begin{array}{l}\text { Praktik Penyusunan Komponen } \\
\text { Penilaian pada RPP }\end{array}$ & $\begin{array}{l}\text { Praktik RPP berdasarkan format sesuai Permendikbud Nomor } 22 \\
\text { Tahun } 2016 \text { ( } 4 \text { jam pelajaran) per individu meliputi teknik, bentuk, } \\
\text { instrumen, penyusunan kunci jawaban/ kriteria, dan rumus penskoran }\end{array}$ \\
\hline 5. & Presentasi hasil praktik RPP & $\begin{array}{l}\text { Praktik menyampaikan hasil (dapat dengan menukarkan produk } \\
\text { dengan teman dan atau layar LCD) }\end{array}$ \\
\hline
\end{tabular}

Konsep Penilaian Kurikulum 2013 disampaikan secara teori dengan alokasi waktu hanya 1 jam pelajaran. Pertimbangannya adalah konsep HOTS dan C-4 yang merupakan konsep penting dalam Kurikulum 2013 revisi telah disampaikan dalam mata diklat Konsep Kurikulum 2013. Selanjutnya, peserta diminta melakukan praktik analisis kurikulum (SKLKI-KD) sekaligus menentukan jenis, teknik, dan bentuk penilaian yang sesuai pada ketiga aspek menggunakan format yang diberi tambahan kolom setelah IPK, yaitu indikator soal; dan jenis-teknik-bentuk penilaian selama 2 (dua) jam pelajaran dengan penekanan pada 
indikator HOTS. Lalu peserta mempraktikkan penyusunan komponen penilaian selama empat jam pelajaran. Setiap peserta membuat produk penilaian. Kegiatan terakhir adalah presentasi hasil praktik dengan saling menukarkan hasil kepada rekan peserta diklat untuk didiskusikan dalam kelompok atau dapat pula dalam diskusi kelas.

\section{PENUTUP}

Kesimpulan penelitian ini sebagai berikut. Pertama, rata-rata komponen dari urutan tidak memenuhi sampai memenuhi adalah komponen indikator soal, kunci/kriteria, rumus penskoran, instrumen penilaian, dan teknik penilaian. Kedua, kelemahan guru IPA MTs dalam menyusun RPP adalah pada komponen indikator soal, kunci/kriteria, dan rumus penskoran. Ketiga, penyebab kelemahan guru adalah penguasaan materi guru yang masih lemah pada beberapa materi yang mendasari, yaitu konsep penilaian Kurikulum 2013; analisis kurikulum; penguasaan KKO; keterampilan menyusun kriteria/rubrik pada jenis penilaian non tes. Keempat, pengembangan kurikulum diklat materi penilaian pembelajaran adalah pada mata diklat penilaian autentik pada Kurikulum 2013 menekankan pada penguatan materi yang mendasari pada penyusunan komponen penilaian pada RPP dan strategi penyampaiannya. Mata diklat tersebut adalah Penilaian sesuai Kurikulum 2013; Analisis Kurikulum; dan Praktik Penyusunan RPP. Strategi penyampaian adalah menambahkan kolom indikator soal, teknik, dan bentuk penilaian pada lembar kerja analisis SKL, KI, dan KD; meminta pembuatan sebagian indikator HOTS; dan koreksi produk dengan sesama peserta.

Berdasarkan kesimpulan tersebut di atas, dapat disarankan sebagai berikut. Pertama, Balai Diklat Keagamaan Semarang dimohon dapat mengajukan pengembangan kurikulum ini sebagai usulan silabus Diklat Teknis Substantif Kurikulum 2013 mata diklat Penilaian Autentik pada Kurikulum 2013. Kedua, widyaiswara diharapkan meningkatkan penguasaan materi konsep penilaian Kurikulum 2013 dan keterampilan menyusun indikator soal dan instrumen penilaian. Ketiga, widyaiswara diharapkan meningkatkan kemampuan penyampaian materi penilaian kepada guru-guru peserta diklat penilaian dengan memanfaatkan waktu sebaik-baiknya.

\section{UCAPAN TERIMA KASIH}

Terimakasih kepada Kepala Lembaga Administrasi Negara Republik Indonesia, Kepala Badan Litbang dan Diklat Kementerian Agama Republik Indonesia, Kepala Pusat Pendidikan dan Pelatihan Teknis Pendidikan dan Keagamaan, dan Kepala Balai Diklat Keagamaan Semarang serta jajarannya atas ijin, kemudahan, dan bantuan penelitian dalam rangka orasi ilmiah menduduki jabatan fungsional widyaiswara ahli utama pada Balai Diklat Keagamaan Semarang sampai selesai. Terimakasih pula kepada kedua reviewer penelitian karya tulis ilmiah Bapak Dr. Andi Taufik, M.Si. dan Bapak Prof. Dr. H. Fatah Syukur, M.Ag. atas segala masukan, perhatian, kesabaran, dan kearifan dalam membimbing penulis. Terimakasih pula kepada guru-guru di Provinsi Jawa Tengah dan Daerah Istimewa Yogyakarta, khususnya guru-guru IPA Madrasah Tsanawiyah. Terimakasih kepada Tim Redaksi Jurnal Edukasi yang telah memuat artikel penelitian ini sebagai persyaratan orasi ilmiah widyaiswara ahli utama. Jazakumullah khoiro jazaa'. Semoga tulisan ini bermanfaat dan dapat memperkaya khazanah wacana penelitian kediklatan.

\section{DAFTAR PUSTAKA}

Aldoobie, N. (2015). ADDIE Model. American International Journal of Contemporary Research 5 (6): 68-72.

Black, P. \& Wiliam, D. (1998). Inside the Black Box: Raising Standards through Classroom Assessment. Phi Delta Kappa, October: 1-13.

Bengio, Y., Louradour, J., Collobert, R., \& Weston, J. (2009). Curriculum Learning. In Proceedings of the $26^{\text {th }}$ International Conference on Machine Learning. Montreal. Canada: Queen Mary, University of London. Citing Internet Sources. URL. https://qmro.qmul.ac.uk/ xmlui/handle/123456789/15972.

Creswell, J.W. (2010). Research Design: Pendekatan Kualitatif, Kuantitatif, dan Mixed. (Terj. Achmad Fawaid). Judul 
Asli: Research Design: Qualitative, Quantitative, and Mixed Methods Approaches. Yogyakarta: Pustaka Pelajar.

Cronbach, L.E. (1990). Essentials of Psychological Testing. New York: Harper and Row.

Crooks, T. (1988). The Impact of Classroom Evaluation Practices on Students. Review of Educational Research 58 (4):438-481.

Dahar, R.W. (1989). Teori-teori Belajar. Jakarta: Erlangga.

Denzin, N.K. \& Lincoln, Y.S. (1994). Handbook of Qualitative Research. California: SAGE Publication, Inc.

Hasan, I. (2002). Pokok-pokok Materi Metodologi Penelitian dan Aplikasinya. Jakarta: Penerbit Ghalia Indonesia.

Republik Indonesia. (2005). Undang-undang RI Nomor 14 Tahun 2005 tentang Guru dan Dosen. Jakarta: Sekretariat Negara.

Republik Indonesia. (2008). Peraturan Pemerintah Nomor 74 Tahun 2008 tentang Guru. Jakarta: Sekretariat Negara.

Republik Indonesia. (2011). Peraturan Kepala Lembaga Administrasi Negara Nomor 13 Tahun 2011 tentang Pedoman Umum Pembinaan Penyelenggaraan Pendidikan dan Pelatihan Teknis, Jakarta: Lembaga Administrasi Negara.

Republik Indonesia. (2012). Pedoman Pelaksanaan Penilaian Kinerja Guru. Jakarta: Badan Pengembangan Sumber Daya Manusia Pendidikan dan Penjaminan Mutu Pendidikan Kementerian Pendidikan dan Kebudayaan.

Republik Indonesia. (2013). Peraturan Pemerintah Nomor 32 Tahun 2013 tentang Perubahan Atas Peraturan Pemerintah Nomor 19 Tahun 2005 tentang Standar Nasional Pendidikan. Jakarta: Sekretariat Negara.

Republik Indonesia. (2014). Peraturan Mennegpan \& RB Nomor 22 Tahun 2014 tentang Jabatan Fungsional Widyaiswara dan Angka Kreditnya. Jakarta: Kementerian Negara Pendayagunaan Aparatur Negara dan Reformasi Birokrasi.
Republik Indonesia. (2015). Peraturan Menteri Agama RI Nomor 75 Tahun 2015 tentang Penyelenggaraan Pendidikan dan Pelatihan Pegawai pada Kementerian Agama. Jakarta: Kementerian Agama.

Republik Indonesia. (2016 a) Peraturan Menteri Pendidikan dan Kebudayaan Nomor 22 Tahun 2016 tentang Standar Proses Pendidikan Dasar dan Menengah. Jakarta: Kementerian Pendidikan dan Kebudayaan.

Republik Indonesia. (2016 b) Peraturan Menteri Pendidikan dan Kebudayaan Nomor 23 Tahun 2016 tentang Standar Penilaian Pendidikan. Jakarta: Kementerian Pendidikan dan Kebudayaan.

Republik Indonesia. (2017 a). Surat Keputusan Kepala Badan Penelitian dan Pengembangan dan Pendidikan dan Pelatihan Kementerian Agama Republik Indonesia Nomor 15 Tahun 2017 tentang Desain Program Diklat Teknis Pendidikan dan Keagamaan. Jakarta: Badan Litbang dan Diklat Kementerian Agama RI.

Republik Indonesia. (2017 b). Surat Keputusan Kepala Badan Litbang dan Diklat Kementerian Agama Republik Indonesia Nomor 62 Tahun 2017 tentang Struktur Kurikulum Pendidikan dan Pelatihan Tenaga Teknis Pendidikan dan Keagamaan Pusdiklat Tenaga Teknis Pendidikan dan Keagamaan. Jakarta: Badan Litbang dan Diklat.

Republik Indonesia. (2017 c). Panduan Penilaian oleh Pendidik dan Satuan Pendidikan Sekolah Menengah Pertama. cet. ke-4. Jakarta: Direktorat Jenderal Pendidikan Dasar dan Menengah Direktorat Pembinaan Sekolah Menengah Pertama Kementerian Pendidikan dan Kebudayaan.

Republik Indonesia. (2017 d). Peraturan Pemerintah Nomor 11 Tahun 2017 tentang Manajemen PNS. Jakarta: Sekretariat Negara.

Kurt, S. 5 Mei 2018. Citing Internet Sources URL https://educationaltechnology.net/theaddie-model-instructional-design/ 
Mehrens, W.A. \& Lehman, I.J. (1984). Measurement and Evaluation in Education and Psychology. $3^{\text {th }}$ ed.Michigan: Holt, Rinehart and Winston, Inc.

Nasution, S. (2006). Asas-asas Kurikulum. ed. ke-2. cet. ke-7. Jakarta: Bumi Aksara.

Nurhajati, W.A. \& Syaiful, B.B. (2017). Pengembangan Kurikulum Pendidikan dan Pelatihan (Diklat) Berbasis Kompetensi dalam Membangun Profesionalisme Pegawai Negeri Sipil (PNS). Jurnal Pendidikan (Teori dan Praktik) 2 (2): 156-164.

Rusman. (2009). Manajemen Kurikulum. Jakarta: Rajawali Pers.

Saylor, J.G., Alexander, W.M., dan Lewis, A.J. (1981). Curriculum Planning for Better Teaching and Learning. $4^{\text {th }}$ ed. Nebraska: Holt, Rinehart and Winston.

Shepard, L.A. (2000). The Role of Classroom Assessment in Teaching and Learning.
CSE Technical Report 517, Center for the Study of Evaluation National Center for Research on Evaluation, Standards, and Student Testing, Graduate School of Education and Information Studies, University of California.

Soetopo, H. \& Soemanto, W. (1982). Pembinaan dan Pengembangan Kurikulum. Jakarta: Penerbit Bina Aksara.

Strauss, A. \& Corbin, J. (2009). Dasar-dasar Penelitian Kualitatif: Tatalangkah dan Teknik-teknik Teoritisasi Data.cet. ke-3. Yogyakarta: Pustaka Pelajar.

Tim. (1989). Al-Qur'anul Karim. Semarang: CV Thoha Putera.

Rosidah. (6 April 2017). Citing Internet Sources. URL http://staffnew.uny.ac.id/upload/1318448 75/penelitian/manajemen+diklat.pdf. 